\title{
Correction to: No evidence of Trichinella spp. in domestic pig carcasses at a selected abattoir in southern Botswana
}

\author{
Basiamisi Ernest Segwagwe ${ }^{1} \cdot$ James Machete ${ }^{2} \cdot$ Mpho Ntwaetsile $^{2} \cdot$ Borden Mushonga $^{3} \cdot$ Erick Kandiwa $^{3}$
}

Published online: 30 April 2019

(C) Springer Nature B.V. 2019

\section{Correction to: Tropical Animal Health and Production https://doi.org/10.1007/s11250-018-1684-6}

The article "No evidence of Trichinella spp. in domestic pig carcasses at a selected abattoir in southern Botswana", written by Basiamisi Ernest Segwagwe, James Machete, Mpho Ntwaetsile, Borden Mushonga, Erick Kandiwa, was originally published electronically on the publisher's internet portal (currently SpringerLink) on 13 August 2018 with open access.
With the author(s)' decision to step back from Open Choice, the copyright of the article changed on August 2018 to () Springer Nature B.V. 2019 and the article is forthwith distributed under the terms of copyright.

The original article has been corrected.

Publisher's note Springer Nature remains neutral with regard to jurisdictional claims in published maps and institutional affiliations.
The online version of the original article can be found at https://doi.org/ 10.1007/s11250-018-1684-6

Basiamisi Ernest Segwagwe

bvsegwagwe@gmail.com

1 Department of Biomedical Sciences, Faculty of Medicine, University of Botswana, P. Bag UB0074, Gaborone, Botswana

2 Department of Animal Science and Production, Botswana University of Agriculture and Natural Resources, Private Bag 0027 ,

Gaborone, Botswana

3 Department of Biomedical Sciences, School of Veterinary Medicine, Faculty of Agriculture and Natural Resources, University of Namibia, P. Bag 13301, Pioneerspark, Windhoek, Namibia 